UNIO - EU Law Journal. Vol. 7, No. 1, July 2021, pp 82-95.

®2021 Centre of Studies in European Union Law

School of Law - University of Minho

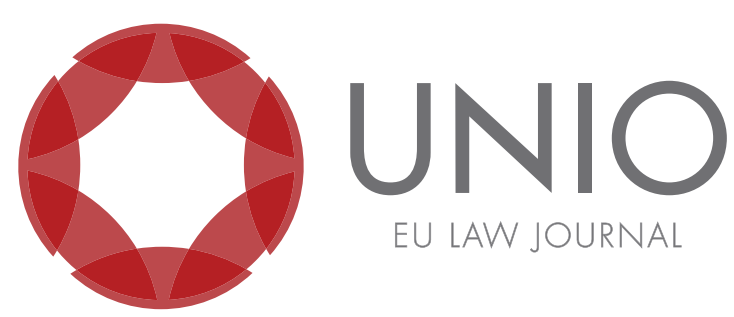

\title{
Local and regional power: its role in European Integration and the protection of the rule of law
}

\author{
Bruno Miguel de Lima Saraiva*
}

ABSTRACT: A failure in administrative approximation, as established by the EU Treaties, tends towards the perpetuation of systems that keep an organisational statu quo favorable to the stagnation of European integration by limiting its spread beyond urban areas to rural areas. The phenomena of asymmetric economic development within Member States, in turn, allows for the maintenance of this organisational and integrative inertia in highly centralised Member States, serving as a one of the engines for the development of anti-EU sentiment and vote. In this sense the reasoning bebind the establishment of local and regional power as a constitutional bulwark against the development of an illiberal or authoritarian list, especially in young democracies, becomes especially important when framed in context with the growth of authoritarian anti-EU movements throughout Europe. This growth, finding an eager bulwark in rural areas, is not coincidental and might be attributed to the distance from the decision-making process that local and regional government struggle with, combined with economic stagnation and difficulties in the use of resources and opportunities that are theoretically afforded by EU membership, leads to the development of anti-EU sentiment, offering political support and democratic legitimacy to projects which oppose the EU and prove detrimental to democratic systems. This paper therefore posits that to safeguard the development of the greater European project and democracy within Member States, there must be an expansion of the very same principles that govern the interactions between Member States and the EU to the subnational level, with a special focus on subsidiarity.

KEYWORDS: Regions - subsidiarity - European integration - rule of law.

\footnotetext{
* Master's student in European Union Law at the School of Law of the University of Minho.
} 


\section{Introduction}

Despite the long-acknowledged view that regional and local governments have the potential to be a driving force in the advancement of European integration, these have taken a backseat in the development of the greater European political project. Instead, alternate, more classically inspired means of integration came to the fore with citizenship taking the forefront. This approach has rewarded the Union with results that while promising are also uninspiring, having failed to capture the collective interest of Europeans throughout the Union. As a corollary, this failure in the development of local and regional government as an engine that would unite Europeans, also resulted in the foundering of preeminence and relevancy for these figures, a cruel fate considering the efforts that the European Union ("EU") has lavished in local and regional government, with the European Cohesion Policy being regarded as the European investment policy.

The importance and value of these administrations, especially regarding the approximation with European citizens is far from being an innovation in the European landscape. In fact, it merely operated in the realisation of Article 1. of the EU Treaty and the structural thoughts it enshrines. It is, therefore, almost fitting that such a deeply rooted failure has led the Union to be confronted with political phenomena which strike at those very core principles in defiance of the investments made, with rural areas providing eager support to political movements that are antagonistic to the EU, and indeed, democratic values, despite deep rural dependence upon the project they eschew.

This paper intends to analyse the reasons for this phenomenon, the interactions that occur between the European Union and the Constitutional and Administrative traditions of Member States to glimpse a solution for challenges that strike at the core of this political project. This, we posit, may be put into motion by bringing back the regions and localities back to the forefront of European integration and citizen interaction.

\section{Contextualisation of the European political panorama}

A common criticism levied against the European Union and presented as a barrier to its greater political aspirations is the so called "democratic deficit" which, in combination with other factors has translated in the national development of Eurosceptic parties in Member States, ${ }^{1}$ eventually finding a seat at a greater European level in institutions like the EU Parliament and the European Council.

A peculiarity about these political manifestations, now ubiquitous within the EU and its Member States ${ }^{2}$ is that not all these political movements are necessarily opposed to the core principles enshrined by the Union. Some of these Movements, eventually represented in Political Groups and Families within the EU Parliament, merely disagree with it in its current configuration, taking exception either to its market economy approach, its Ordoliberal inspired system of social guarantees or by opposing its federalising project. In this sense, despite opposition to the development

\footnotetext{
${ }^{1}$ Vivien A. Schmidt, The Eurozone's crisis of democratic legitimacy: can the EU rebuild public trust and support for European Economic Integration? (Luxembourg: European Commission's Directorate-General for Economic and Financial Affairs Discussion Paper, Publications Office of the European Union, 2015), 18.

${ }^{2}$ Catherine E. De Vries and Erica E. Edwards, “Taking Europe to its extremes: extremist parties and public euroscepticism”, Party Politics, v. 15, no. 1 (2009): 5-28, https://doi.org/10.1177/1354068808097889, 6.
} 
of Union along current lines, these political forces are not necessarily opposed to its existence. They just disagree on what should be its purpose, mechanisms, or objectives, clamoring for changes to its core values and systems, or a return to the preeminence of state sovereignty and in Westphalian conceptions. However, due to the nature of European political integration and its intentionally deliberate pace, this opposition generally only translates in a slowing of European integration. ${ }^{3}$

Despite the apparent threat that these political developments show toward the development the greater European project, they share a myriad of core values such as the democratic principle, rule of law, and a respect for fundamental rights in such a way that still upholds and protects EU citizens. Due to those very same combined values and principles, their protection and continuation is not threatened by these forces, which in turn translates in an accidental reinforcement of European integration, and through it, the EU. This occurs because through this sharing of core values, even if a political movement is outwardly opposed to the EU, they are not opposed to the furthering of these values by it, allowing for a slow but intense development of a system based on mutual dependency between Member States and the greater EU project even if political forces within them are nominally opposed. This means that far from these politically opposed movements being detrimental to the Union, they assist in its sedimentation and legitimisation in the sense that this outward dichotomy whilst sharing a set of basic principles gives body to the realisation of the democratic principle and furnishes precious feedback in the integration process without a complete rejection or calls for disbanding. Therefore, we must consider that certain stances though formulated in opposition to the European project may serve to reinforce the project in the long run by defining the ideal rate of integration. Through this slowing and establishment of boundaries to the EU's scope of action occurs safeguarding of interests held by certain Member States and citizens who more zealously seek to maintain elements of traditional national sovereignty, for whatever reason deemed necessary. If a subsequent need for integration in these previously "gated off" areas is deemed necessary, this need would only serve to legitimise the Union's eventual intervention while increasing its visibility in said intervention. The element of visibility and the perception of the EU as a powerful tool for the solution of issues seldom resolved using more traditional means. This is an essential element in further justifying and therefore strengthening and legitimising its federalising project.

In stark opposition with this moderate Eurosceptic school of thought, manifested within every part of the political spectrum, an emerging set of political movements present a much more pressing challenge to the larger European project due to their opposition, not only, to the very values that lie at the base of not only the EU, but of the constitutional identity of Member States and greater democratic principles. ${ }^{4}$ These movements, characterised by authoritarian stances have enjoyed a gradual implementation, not just in Europe, but throughout the globe being termed illiberal democracies. ${ }^{5}$ These regimes, often headed by so called "strongmen" tend

\footnotetext{
${ }^{3}$ De Vries and Edwards, "Taking Europe to its extremes", 10.

${ }^{4}$ Han Werts, Peer Scheepers and Marcel Lubbers, "Euro-scepticism and radical right-wing voting in Europe, 2002-2008: social cleavages, socio-political attitudes and contextual characteristics determining voting for the radical right", European Union Politics, v. 14, no. 2 (2013): 183-205, doi: $10.1177 / 1465116512469287$.

${ }^{5}$ Fareed Zakaria, “The rise of illiberal democracy”, Foreign Affairs, v. 76, no. 6 (1997): 22-43, 22-24.
} 
to show a conservative, assertive and anti-system stance, endeavouring to create an appearance of control and order through the use of conflict, be it legislative, political or physical. ${ }^{6}$ Through the combination of these characteristics and the inevitable interactions at a global scale, these phenomena have mostly presented themselves in Western democracies as positioning themselves in the far-right of the political spectrum. ${ }^{7}$ One should note that this type of thought in Europe tends to manifest itself in a new and much more worrying variety of Euroscepticism than the one previously mentioned. These political projects present themselves as being directly opposed to the European project, often being based on an anti-system, anti-integration and nationalistic platform, claiming to uphold the interests of the citizens of the Member States and that they are operating in opposition to the perceived abandonment by the greater European political system. ${ }^{8}$ In this way, the core principle base directly opposes itself to the values of the Union to which we made previous mention, claiming for a return to values and a statu quo that not only is impossible in a modern context, but possibly that never was present. ${ }^{9}$

In this way, not only is there a clash of perspectives on policies regarding economic and social development, or a disagreement on the rhythm of European integration and approximation, but a value and ideological confrontation. The development of a political discourse that calls for the "recovery" of potentially unattainable values is especially seductive in the sense that it simply promises the recuperation of historical stances. Within these promises towards the adoption, with historic stances also comes a tacit promise of the recovery of certain social or economic equilibriums which are particularly appealing in regions or groups who suffer from a rising gap in inequality. These political forces, therefore, do not truly aim to impede the continuation or undermine the existence of the European project, instead showing a disinterest in the core values which underline the EU political construction. However, precisely due to this disinterest, the rights acquired by European citizens by their enfranchisement into the EU are put in a position liable to erosion by these political manifestations which can eventually lead to a weakening of European integration and through it, the greater peace project that serves as a prius to the EU.

\section{The role of the regions and local government in this statu quo}

With this short overview over the democratic state of the Union, one can consider in what way these problems interact with one of the greatest hurdles that European legitimacy faces, the so called "democratic deficit", and its connection to the institutional language and organisation of local and regional power within the European Union. It is to note that this democratic deficit is one of the more frequent criticisms levied by Anti-EU political movements at the European Union

\footnotetext{
${ }^{6}$ Yahor Azarkevich, "A strongman at home is a strongman abroad? Investigating operational Codes of Aliaksandr Lukašenka and Donald Trump” (Master's Thesis, Cracow: Jagiellonian University - Faculty of International and Political Studies - Institute of European Studies, 2020) and Heino Nyyssönen and Jussi Metsälä, "Liberal democracy and its current illiberal critique: the emperor's new clothes?", Europe-Asia Studies, v. 73, no. 2 (2020): 273-290, doi: 10.1080/09668136.2020.1815654, 277.

${ }^{7}$ Werts, Scheepers and Lubbers, "Euro-scepticism and radical right-wing voting in Europe".

${ }^{8}$ De Vries and Edwards, "Taking Europe to its extremes", 8 and Azarkevich, "A strongman at home is a strongman abroad?".

${ }^{9}$ Nyyssönen and Metsälä, "Liberal democracy and its current illiberal critique”, 283-285.
} 
and rival political movements within Member States, under the ostensive banner of democracy values and the upholding of customary values and public will.

In this context, an urban/rural split in anti-EU voting has already been identified by organs and institutions of the European Union, with studies regarding this issue having been commissioned to identify the reason for this phenomenon. ${ }^{10}$ As we previously mentioned, not all anti-EU movements have at their core an ideological opposition to the principle and value base of the EU. Indeed, many of them claim to champion cultural, constitutional, and intra-national diversity, but the rise of political movements and ideological stances that are, de facto, contrary to these elements presents a concern. This concern is bellied by the remarkable electoral achievements that these stances show, with these political movements placing figures in high office and decision-making spheres in several Member States, forcing us to consider why exactly rural areas present themselves as a fertile political ground for the development of these movements.

In a 2020 Working Paper by the European Commission titled "The UrbanRural Divide in Anti-EU Vote", three factors are identified as being determinate, (i) growth in local unemployment levels, (ii) low voter turnout rates, (iii) a higher share of people born outside the EU (with the tendency reversing itself with a higher rate of population born in other EU Member States). After these factors, the factors of greatest importance were an aged population, a faltering regional economy, and a lower percentage of the population with tertiary education degrees, the regional and socio-demographic variables. ${ }^{11}$ Even a cursory examination of these elements reveals the intimate connection between a region's economic development and their eventual demographic repercussions. Considering the effort that the EU takes into the development of its regions and how, conceptually, it strives for gradual economic development of the entire European territory, not merely the Member States unitarily, we must wonder why their efforts offer such contradictory results. Indeed, with the Economic Cohesion plan, absorbing nearly a third of the entire EU Budget between 2014 and 2020, and ranking as the principal investment policy of the Union, we must consider why this effort seems to fail in the eyes of the intended beneficiaries. ${ }^{12}$

Far from being a subject with mere political, electoral, or programmatic interest, this is a subject that speaks at the heart of the European construction. The principles of European solidarity, an outgrowth from the greater principal of loyalty, is supposed to operate as a counterweight to the blind application of certain demands and behaviours. ${ }^{13}$ Despite its origins in the regulation of interactions between Member States, it remains a constant reminder that in order for the European Union to remain as a cohesive construction it requires a measure of empathy and intersubjectivity. This intersubjectivity however, cannot merely be applied between Member States, but also between regions and local governments at a multinational level and within Member States regarding these forms of government.

\footnotetext{
${ }^{10}$ Laura de Dominicis, Lewis Dijkstra and Nicola Pontarollo, The urban-rural divide in anti-EU vote: social, demographic and economic factors affecting the vote for parties opposed to European integration (Luxembourg: Directorate-General for Regional and Urban Policy Working Paper, Publications Office of the European Union, 2020).

${ }^{11}$ De Dominicis, Dijkstra and Pontarollo, "The urban-rural divide in anti-EU vote", 15.

12 “The EU's main investment policy”, accessed June 15, 2021, https:/ / ec.europa.eu/regional_policy/ en/policy/what/investment-policy/.

${ }^{13}$ Klaus Stern, Derecho del Estado de la Republica Federal de Alemania (Madrid: Centro de Estudios Políticos y Constitucionales, 1987).
} 
One cannot escape the reality that without an economic equilibrium, fostered by this European solidarity, the cornerstone of European political construction that is the common market is put into serious doubt if a perception of economic asymmetry seeps through. ${ }^{14}$ The idea that there are groups that benefit disproportionally from such an economic community, or even that others benefit to a lesser extent in comparison, undermines any political system that is built over it. The disintegration of this shared foundation would only serve to undermine any identity or political developments made towards European integration and without these shared identities being developed sufficiently to contend with narratives which call for a past marketed as fallow of such asymmetries, it results in the European project being portrayed as oppressive to the economic and democratic self-determination of the peoples of Europe. ${ }^{15}$ The implementation of these perspectives, therefore, operates as a prius to the development of the resentment and recuperation of historical conflicts that function as a political tool in the affirmation of these political movements. A system that results, or merely appears to result in a group benefitting while another is exploited is a grave threat to the development of a European project by operating as a catalyst to recuperation of rivalries, factionalism, and the growth of nationalist movements, shortly abandoned but seemingly long forgotten. In that sense, one can claim Europe as a victim to its own success. By bringing such a level of integration and economic development to the Member States, it has reached a point in which these seemingly do not recognize their dependence to the political construction they have bound themselves to. One must recognise that these difficulties, far from being a flaw in the implementation of the European community, are an intended characteristic of European approximation serving, as mentioned previously, as a barometer for the rate of integration preventing it from being intolerably swift. This very same slow, deliberate pace that allows for the underlying plan of gradual implementation to be forgotten, allows its attack by political agents eager to profit (often materially as well) from its subversion.

Far from only impacting Member States however, this dynamic has internal repercussions, harkening to the challenges witnessed in a more Westphalian conception of national sovereignty. Indeed, in the aftermath of Brexit both pro- and anti-European observers raised the specter of Balkanization as a looming challenge faced by the EU and both former and current Member States in coming years, owing to internal conflict and the establishment of groups positioning themselves for or against greater self-determination. ${ }^{16}$ For these reasons, the importance of the Principle of solidarity as an escape valve has never been higher in this role as a moderator in the interactions between Member States, though perhaps even more importantly, within them. One often forgotten requisite inherent in the Principle of European solidarity however, is trust. ${ }^{17}$ For this trust to be rewarded with tangible results, a

\footnotetext{
${ }^{14}$ This thought pre-exists the Ordoliberal conceptualization as per Alexander Hamilton, "Federalist no. 12", in The Federalist Papers, eds. Alexander Hamilton, James Jay and John Madison (New York: Palgrave Macmillan, 2009).

${ }^{15}$ Francesco Nicoli, "Democratic deficit and its counter-movements: the Eurocentric-Eurosceptic divide in times of functional legitimacy", in Anti-Europeanism: critical perspectives towards the European Union, ed. Marco Baldassari, Emanuele Castelli, Matteo Truffelli and Giovanni Vezzani (Springer, 2019), 13-29.

${ }^{16}$ Vasko Naumovski, "Europeanization of the Balkans, or Balkanization of Europe?”, Georgetown Journal of International Affairs, v. 20, no. 1 (2019): 120.

${ }^{17}$ Jean-Claude Barbier, "Languages, Political Cultures and Solidarity in Europe", Online Working Paper
} 
measure of administrative deconcentration, through for example the delegation of responsibilities, is necessary to allow for the regional development within Member States as the application of funds requires effective governance and a measure of self-determination to, at the very least, determine investment priorities. ${ }^{18}$ Without these essential governing tools one cannot foresee a way in which these Regions, Municipalities and Local Governments will develop the means and institutional experience that would allow them to take full advantage of the opportunities afforded to them not only by Member States provide, but by the European Union and support structures in the European Council. ${ }^{19}$

\section{The organisation of regional and local administrations and their role in European integration}

The convergence of administrative law between Member States has been recognised since at least the 1970's, with Community Law being a significant factor in this development through a reciprocal influence between judicial systems. ${ }^{20}$ These examples present themselves as an example of substantial European integration with Jürgen Schwarze recognising that though in a first stage, European administrative systems informed the development of $\mathrm{EU}$ law, ${ }^{21}$ in a second stage this tendency reversed, with EU law affecting the development of national legal systems. ${ }^{22}$ In this paper we consider particularly relevant the alterations that arise from this latter interaction, especially at an administrative subnational level.

Considering that the Union, as previously mentioned, considers regional development as one of its core priorities, ${ }^{23}$ the extension of resources and support that permit for these investments to have a material effet utile also becomes a tacit priority. Indeed, only through this effet utile can there be a justification for the trust that underlines these initiatives. However, for these investments to have an effect, one cannot discount the impact that gaps in competence and administrative organisation have in the facilitation or hindering in the use of investment or support. Administrations at a local and regional level are in a privileged position to combat the marginalisation of non-urban areas, marginalisation which results in the perception of abandonment and in distrust for a larger European project that ironically, considers them one of its preeminent considerations. No matter its volume or nature, an investment that does not present lasting structural effects in the intended region will

no. 01 (Helsinki: RECODE - Responding to Complex Diversity in Europe and Canada, 2012), 6-8.

${ }^{18}$ Rajeev Goel, Ummad Mazhar, Michael Nelson and Rati Ram, "Government Decentralization and International Government Performance”, CESifo Working Paper Series, no.6013 (München: Center for Economic Studies and Ifo Institute, 2016), 2 and 16.

19 Thomas A. Vandamme, "Still the Committee of 'Legislative Regions'? On heterogeneity, representation and functionality of the Committee of the Regions after 2004", Amsterdam Law School Legal Studies Research Paper Series 2013-15 (Amsterdam: Amsterdam Centre for European Law and Governance, March 13, 2013), 27-28.

${ }^{20}$ Sophie Fernandes, "Administração Pública", in Direito da União Europeia - elementos de direito e políticas da União, ed. Alessandra Silveira, Mariana Canotilho and Pedro Froufe (Coimbra: Almedina, 2016),73163.

${ }^{21}$ One could almost establish a nexus between this administrative approximation and European interconstitutionality through the influence exerted in the principle and value core of the Union. Considering of the way that administrative systems derive from a state's Constitutional framework. ${ }^{22}$ Sophie Fernandes, "Administração Pública”, 86.

${ }^{23}$ This is one of Europe's constant objectives taking form not just in policy or declarations, but more importantly, also as a monetary investment, as previously cited. 
not be effective in combating neither a rapidly increasing economic gap, but perhaps more relevant for the issue at hand, the self-perception of marginalisation.

In order to take to access these lines of support and assess the merits of alternative implementation plans in a manner that offers meaningful results, local and regional administrations require a measure for a basic cast of competencies, institutional complexity and basic integration in the greater European panorama. ${ }^{24}$ The proximity and approximation between these forms of government and the population they represent may prove a powerful advantage by allowing for a keener understanding of the characteristics of that polity. ${ }^{25}$ Beyond a mere resource, geological, geographic and demographic assessment, this proximity allows for the factoring of elements such as cultural practices, specialised knowledge bases and historical factors which would be difficult to factor by outside observers. For the development of plans that take advantage of these specific and valuable, yet often ignored characteristics, one needs the technical and institutional capability and maturity to aid in the implementation of development projects. This requirement is constant no matter the source of the investment be it European or otherwise, therefore, more important than the recognition of the origins of this investment, it must prove useful to reduce the feeling of distance from policy makers.

In addition to this experience, these forms of government require the capacity, competence and powers that allow them to put into practice policies that allow for regional development. The need for these powers is twofold: the: (i) need for a swift and effective implementation of these resources, by reducing or eliminating the roadblocks regarding the capacity of these local administrations to implement policy; and (ii) the need for the development of technical experience and capacity allowing these administrations to determine the value of the various options to select the ones that will have the greatest effet utile.

In this second point, the inefficient use of these resources may translate in a breach of the Principle of European solidarity, namely in the aforementioned component of trust, manifesting in the expectation of utility and the use of these investments in the most effective way possible. ${ }^{26}$ An outside observer lacking context and accustomed to a well-developed administrative reality is unlikely to recognise the unique challenges that specific institutional or organic deficits may pose, perceiving an inability to act in a manner that best utilises these opportunities as corruptive or deliberately wasteful actions. One cannot forget that the Principle of solidarity, corollary to the Principle of European loyalty, carries a strong bilateral component in the sense that one party cannot discharge their dully held responsibilities.

This means that one party cannot "take advantage" of said principle to enjoy this solidarity beyond strict necessity. Additionally, this administrative discharge of responsibility may put into question the very Principle of proportionality, as partially codified in Article 5. (4) of the TEU, in the sense that less grievous or costly measures should not be adopted in lien of more administratively expedient options when the limitations are considered.

\footnotetext{
${ }^{24}$ Mindaugas Butkus, Diana Cibulskiene, Alma Maciulyte-Sniukiene and Kristina Matuzeviciute, "What is the evolution of convergence in the EU? Decomposing EU disparities up to NUTS 3 level", Sustainability, v. 10, no. 5 (2018), 22, doi:10.3390/su10051552.

${ }^{25}$ Paul Blokker, "The constitutional premises of subnational self-government in new democracies", Corvinus Journal of Sociaoloy and Social Policy, v. 3, no.1 (2012), doi: 10.1426738.

${ }^{26}$ Sophie Fernandes, "Administração Pública”, 136.
} 
Returning to our previous thoughts regarding the organisation, capacity, and attributions to subnational administrations, it is important to note that this is a matter normally under the exclusive purview of Member States, being perceived as being core to their constitutional identity. This is explicitly referenced in Article 4. ${ }^{\circ}$, section 2 of the European Union Treaty, defining the respect of national identities "[inherent] in their fundamental structures, political and constitutional, inclusive of regional and local selfgovernment", as one of European Union's core principles. Additionally, it is bound to a respect for the essential State functions "including ensuring the territorial integrity of the State (...)", our bold emphasis.

As expressly indicated by the Treaties, these subjects cannot be determined by the EU falling under the sole purview of the initiative of the Member States themselves. Indeed, the sheer proximity section 3 of Article $4 .^{\circ}$ to the aforementioned Section 2 seems to imply that Member States have a further duty to assist in the maintenance of this territorial and State Sovereignty through their actions which: "[assist $]$ each other in carrying out tasks which flow from the treaties". It is, therefore, relevant to revisit one of the more curious innovations brought about by the Lisbon Treaty regarding the Principle of subsidiarity as defined in Article 5. ${ }^{\circ}$, section $3 .^{\circ}$ of the TEU by defining that the Union acts outside the realms which are not of its exclusive competence only if and in so far as the objectives of the proposed action cannot be sufficiently achieved by the Member States. ${ }^{27}$ This principle however, also applies at a local and regional level while still allowing action at the EU level in order to better safeguard its objectives or maximise the utility of said act due to their scope or effect. This is, at first glance, a further confirmation of the EU's inability to act in the direction of decentralisation and devolution of powers in heavily centralised, unitary Member States. ${ }^{28}$ However, a particularly broad interpretation of this Principle may determine that these dispositions in the Treaties not only operate as a starting point for this devolution of competences but enshrine a duty on the part of Member States towards that end. By following this broad interpretation one can find the basis for the argument that a particularly centralised and unitary Member State is failing in its obligations regarding EU law in the sense that it claims competency and capacity for actions that could sufficiently be achieved at a local or regional level. This interpretation, perhaps even bolder than what the Court of Justice of the European Union ("CJEU") would tend towards, finds justification in the constitutive Treaties. Article 1 of the TEU declares: "This Treaty marks a new stage in the process of creating an ever-closer union among the peoples of Europe, in which decisions are taken as openly as possible and as closely as possible to the citizen.", our emphasis. We therefore, put forward that the Principle of subsidiarity not only compels a respect on the EUs part towards Member States, but also between Member States and finally, between them and their local and regional administrations, truly and literally closer to the citizens. ${ }^{29}$

Such a broad interpretation is, as was mentioned previously, almost a challenge to the constitutional traditions of Member States and their enshrined diversity, surely leading any discussions in this subject to become potentially mired in a political and ideological minefield. This would hazard the greater European integration by stoking and reviving fears, perhaps unfounded had a deeper integration taken place, of a European "Balkanization". However, it is not beyond the realm of possibility that

\footnotetext{
${ }^{27}$ Sophie Fernandes, "Administração Pública", 104.

${ }^{28}$ Thomas Vandamme, "Still the Committee of 'Legislative Regions'?", 16.

${ }^{29}$ Thomas Vandamme, "Still the Committee of 'Legislative Regions'?”, 16-17.
} 
this interpretation of the Principle of subsidiarity will be more widely accepted if, by means other than the CJEU's purview, a trend towards decentralisation takes root on the autonomous but concerted initiative of these local and regional administrations.

The analysis of the potential role that institutions, organs and organisms of the UE can operate towards the reduction of the high levels of voter absenteeism that are present at a rural level should consider the potential that this political empowerment can have in the economic development of these regions. An analysis of the economic potential that this devolution and decentralisation of the regions should be further examined as it could prove to be a powerful tool in the advancement of these principles, enshrined in the Treaties in the face of Member States who would otherwise be reluctant to undertake in these alterations by using their economic frailty as a justification.

\section{The Committee of the Regions}

Once hailed by certain authors as a crucial engine for European integration, ${ }^{30}$ this advisory body with consultative functions was hailed as a potential forerunner to avant la letre multilevel governance. Through the approximation of federalising forces and regionalising interests within the Union, this project was to herald a new EU. ${ }^{31}$ Though this prediction did not come to pass, one should not take this outcome as indicative of this body's potential to foster said integration. Indeed, certain authors have expressed the possibility that the Committee of Regions ("CoR") can develop in a way analogous to the European Parliament and become a European Institution in its own right, ${ }^{32}$ developing a greater influence in the EU's legislative process. ${ }^{33} \mathrm{In}$ that regard, the Treaty of Lisbon has already taken steps by expanding the number of areas in which the CoRs consultation is mandatory. Beyond this, and perhaps even more relevantly, data indicates that their opinions translate into legislative results through its influence in the initiatives undertaken by the Commission, with certain areas being considered as especially fertile. When one considers the role that the Commission has in the European Legislative Process, we can glimpse in what way this intervention can be valuable not just for the CoR but to the interests that it advances. With the alterations to Article $263{ }^{\circ}$ of the TFEU defining the CoR as a semi-privileged plaintiff with the legitimacy to initiate an infringement procedure to safeguard their prerogatives, ${ }^{34}$ one can see how this organ is beginning to take shape in the EU decision making apparatus. These mechanisms, put in place by the Lisbon Treaty allow for the CoRs intervention when its consultative functions are put into question by the Commission, these very same mechanisms having been used by the European Parliament in its institutional development. ${ }^{35}$ This puts into focus the

\footnotetext{
${ }^{30}$ Rosarie E. McCarthy, "The Committee of the Regions: an advisory body's tortuous path to influence", Journal of European Public Policy, v. 4, no. 3 (1997), 441, doi:10.1080/13501769780000091.

${ }^{31}$ Thomas Vandamme, "Still the Committee of 'Legislative Regions'?”, 5.

32 Petr Kaniok and Lenka Dadová, "Committee of the Regions: from advisory body to the second chamber of the European Parliament", Transylvanian Reviewof Administrative Sciences, no. 40E (2013): 114-136.

${ }^{33}$ Petr Kaniok and Lenka Dadová, "Committee of the Regions".

34 Thomas Vandamme, "Still the Committee of 'Legislative Regions'?”, 14.

${ }^{35}$ Justus Schönlau, "Beyond mere 'consultation': expanding the European Committee of the Regions' role”, Journal of Contemporary European Research, v. 13, no. 2 (2017): 1172, and Mechthild Roos,"Far beyond the Treaties' Clauses: the European Parliament's gain in power, 1952-1979", Journal of Contemporary European Research, v. 13, no. 2 (2017): 1055-1075.
} 
possibility of the CoR taking a similar trajectory in the future, despite it not showing that intent now.

From the start the CoR's development roadblocks were identified in its institutional growth as resulting from competing interests within the Committee itself, namely the rivalry between regional and local interests. ${ }^{36}$ This clash of perspectives and interests was only put into sharper focus by the structure of the Committee due to its fundamental goal of providing a voice to all Member State's sub-national authorities, regardless of administrative structure or whether said Member States had administrative regions at all. This meant that local and regional interests had to be present and compete to be heard within the same organ ${ }^{37}$ despite the clear asymmetries between them in terms of institutional and technical capacity, allowing for internal domination of those who were better prepared for such a participation.

The result of this competition is that administrative regions, due to their greater institutional experience, importance, and prestige and especially those with greater competencies, self-determination, and governance capabilities like those of Belgium and Germany were able to develop a measure of ascendancy within this organ. Through the use of what has been described as institutional "shock and awe" tactics in regards to the choice of representatives, often opting to choose ministers of regional governments, these regions were able to monopolise the Committee's agenda. ${ }^{38}$ Though an outwardly positive influence for the development of the CoR, this monopolisation meant that the Committee served to assure the interests of these very same regions, placing in second stage the interaction and mutual development of more fragile or inexperienced members though the use of their voting power towards the implementation of agendas that though mutually useful did not act towards the coordination and devolution of subnational competences as these regions had already achieved.

From this perspective, in a way confirmed by more recent interviews regarding interactions within the CoR, representatives indicate that despite initially existing substantial differences in position, these had dissipated with the committee having since adopted a more harmonious modus vivendi. ${ }^{39}$ One may posit that the adoption of said modus vivendi derived from the recognition and acceptance of the advantages derived from the influence that the technical capabilities afforded by the informal leadership of influential regions brought. For this reason, we consider that the potential of the Committee of Regions has not yet been fulfilled and shall not be fulfilled until there is an effective coordination of interests at a local level, represented by the more developed regions. This is because without this capability to organise and compete with the interests of these larger regions, smaller or less developed regions and local administrations will remain unable to truly find their voice within the CoR as equal partners and advance their interests.

It is telling that Member States seem to have encouraged this early factionalism, in a strategy dubbed by Vandamme as a veritable "divide et impera". ${ }^{40}$ Member States' capacity to nominate the members of the CoR, their national assembly's defining of terms in which such a nomination occurs is entirely advantageous to the perpetuation

\footnotetext{
${ }^{36}$ Thomas Vandamme, "Still the Committee of 'Legislative Regions'?”, 17.

${ }^{37}$ Thomas Vandamme, "Still the Committee of 'Legislative Regions??”, 19-20.

${ }^{38}$ Thomas Vandamme, "Still the Committee of 'Legislative Regions'?", 21 and 27.

${ }^{39}$ Thomas Vandamme, "Still the Committee of 'Legislative Regions'?", 24.

${ }^{40}$ Thomas Vandamme, "Still the Committee of 'Legislative Regions'?”, 19.
} 
of power structures and internal political organisation, especially if it already follows a highly centralised structure. Those local and regional government structures which have already secured a high level of internal autonomy and decentralisation have already secured the capability to ensure their position in the CoR in advantageous terms. In contrast, those systems which have not attained a high level of devolution are subject to the political whims and outcomes of national level policy makers or momentary capacity to endeavour in such reforms. A factor contributing to this gap is the variation in the means of selection of representatives with certain countries such as Portugal and the Netherlands not having a legislated system for the selection of these representatives, contrasting with Austria which has attributed this selection constitutional dignity. ${ }^{41}$

The expansion of competence at a local level through the leveraging of a coordinated stance towards that effect, far from merely implied, was an explicit expectation held by some of the new representatives who entered the CoR upon the EU's expansion in 2007. Further, there was incipient support for the development of regional administration on the part of the EU in some of the new democracies admitted to the EU, precisely as a bulwark towards their democratic and liberal development. ${ }^{42}$ Upon this expansion, a Polish representative stated his hope that this organ could lead to an eventual reinforcement of the Polish regional system (Woiwods). ${ }^{43}$ This is relevant in the sense that perhaps the largest roadblock recognised in the development of the Committee of Regions was the organic and administrative diversity of its members, a necessary consequence of the different constitutional traditions of each Member State and its administrative ramifications. This incorporation of different administrative realities has been recognised as a source of legitimacy of the Committee, proving itself as a forum capable of receiving a plethora of perspectives and diverse administrative realities. However, as recognised by multiple authors, the downside of this plurality is that it serves as a barrier to the CoR's capacity to reach a consensus and deliver coordinated action, to its and its members' own detriment. Indeed, some have recognised this as the greatest challenge that the CoR faces due to the difficulties presented regarding substantive action and basic institutional communication. ${ }^{44}$

For these reasons, we consider that there is a necessity for approximation regarding administrative organisation with a heavy focus on the institutional language, modus operandi and basic organisation of these forms of local and regional administration. This would allow local and regional governments to engage in coordinated activity, allowing for a greater policy implementation capacity and a more effective safeguard of local governance interests. This need is justified by the disparity in interests witnessed between local, regional and highly developed regional representation within the CoR, constraining its development and preventing this organ from creating an effective political pressure loop towards the devolution of powers to underdeveloped forms of local and regional governance. Through this process, administrations who have not quite reached this level of institutional development and devolution have the potential to utilise the resources that they have access to in a more efficient manner, regardless of origin of said resources but with

\footnotetext{
${ }^{41}$ Thomas Vandamme, "Still the Committee of 'Legislative Regions'?”, 21, 27 and 28.

${ }^{42}$ Paul Blokker, "The Constitutional Premises of Subnational Self-Government in new democracies", 53.

${ }^{43}$ Thomas Vandamme, "Still the Committee of 'Legislative Regions'?", 17.

${ }^{44}$ Thomas Vandamme, "Still the Committee of 'Legislative Regions'?”, 17.
} 
a special focus on those with an EU origin since these do not stem from Member States' capacity or willingness to act individually. Using the economic development that the Single Market allows, these forms of local governance can achieve the capacity and legitimacy to advance these emancipating projects. In this way, the CoR can serve as a point of contact and reflexive approximation, allowing for a political osmosis between local and regional polities so that they may, at their own initiative, jump start their approximation in administrative organisation. In this manner and having achieved their once expected goal of being privileged units of European integration, they can further approximate governance to the citizenry.

Beyond the CoR, the European Grouping of Territorial Cooperation may serve this purpose of a point of communication and coordination. One must take into account however, that what appears to have a been a precautionary measure against EU-led administrative decentralisation, this body's instruments cannot not be used to bypass constitutional law of Member States, a stance described as "in deference" towards their Constitutional identities. ${ }^{45}$ This prohibition however can be surpassed if this approximation occurs on the initiative of local and regional government themselves, at an internal/national level, and coordinated a European level with partners from other Member States. This would mean that rather than operating through legislative instruments or decisions it could act as a Parliament, it its etymological sense. In this regard, the CoR has a significant advantage in the sense that it already self-organises by political groups in terms of political filiation, ${ }^{46}$ thereby approximating it to the European Parliament and allowing a dialog between representatives of different Member States without the restrictions of national political rivalries. This allows for a separation of the regional/local dichotomy by grouping together politically similar partners independent of their vertical organisation within the Member State they represent and surpassing the local/regional level schism that was previously witnessed.

\section{Reflections and conclusions}

A failure of administrative approximation leads to the perpetuation of systems that keep an organisational status quo favorable to the stagnation of European integration by not allowing its spread beyond urban areas to rural areas, as these are the ones who most profit from regional and local organisation.

The reason these mechanisms allow for the maintenance of this organisational and integrative inertia in highly centralised Member States is due to the observed phenomena of the economy of Member States converging with that of the Union, while within these same Member States said development is far from uniform. Indeed, research indicated that there is a tendency for the development of economic asymmetries along urban/rural lines in these highly centralised states. ${ }^{47}$ As previously mentioned, these economic asymmetries are one of the main factors in the development of anti-EU vote. Using the vote of European constituents as a barometer for their acceptance of the greater European project, we can trace how resentment levied is at the EU for this economic and eventual demographic disintegration. Economic and demographic factors being identified as the main factors leading to this anti-EU vote allows us to connect the origins of this phenomena to the mechanisms that allow

\footnotetext{
${ }^{45}$ Thomas Vandamme, "Still the Committee of 'Legislative Regions'?”, 18.

${ }^{46}$ Thomas Vandamme, "Still the Committee of 'Legislative Regions'?”, 27-28.

${ }^{47}$ Mindaugas Butkus et al., "What is the evolution of convergence in the EU?”, 22.
} 
these asymmetries to develop and be maintained. In this sense, the hope expressed by the previously alluded to Polish representative to the Committee of Regions proved to be almost clairvoyant by showing the reasoning behind the establishment of local and regional power as a constitutional bulwark against the development of an illiberal or authoritarian list, especially in young democracies. ${ }^{48}$

The growth of authoritarian anti-EU movements and their prevalence in highly centralised new democracies has not escaped notice by certain authors. ${ }^{49}$ We posit that through the aforementioned mechanisms, this growth isn't coincidental since the distance from the decision making process that local and regional government struggle with, combined with difficulties in the use of resources and opportunities that are theoretically afforded to them by their EU membership, leads to the development of anti-EU sentiment, offering political support and democratic legitimacy to projects who oppose the EU and due to their political posturing, are detrimental to local/ regional interests.

The mere appearance that the European project results in an asymmetry of opportunities that lead to the development and maintenance of privileged and underprivileged groups within the EU, was previously cited by us as one of the greatest challenges to its survival. This belief strikes at the heart of the economic construction and the very way the entire system was designed and implemented, putting into doubt the shared identity and solidarity which has been strived for. Indeed, this reality has long been considered as a structural element regarding interactions between Member States, we merely posit that the same interactions occur within them, at a sub-national level. Europe being host to a trove of historical and cultural wealth also bears the wounds of that development, with conflicts and rivalries seemingly forgotten but easily stoked to conflict. These very same conflicts do not end at the Member States' borders but are invisibly traced along the face of Europe within States. In this sense, as surely as the European Union is a peace project between nations, it is also for communities.

For these conflicts to not mortgage the development of the greater European Project, there must be an expansion of the very same principles that govern the interactions between Member States at a subnational level. Solidarity, Trust, Subsidiarity and Equality cannot be ignored within Member States as this only results in a form of complete reverse discrimination in which marginalised areas, unable to seize the opportunities that are offered to them due to simple institutional frailty, are deprived of the opportunity to create a more prosperous future and reap the benefits of European integration.

\footnotetext{
${ }^{48}$ Alex Marx et al., "Multilevel Protection of the rule of law and fundamental rights -the role of local and regional authorities and of the Committee of the Regions", Committee of the Regions Study, 2014, accessed June 18, 2021, doi: 10.2863/10131.

${ }^{49}$ Paul Blokker, "The Constitutional Premises of Subnational Self-Government in new democracies”, 36.
} 